\title{
CENTRO DE CULTURA E LITERATURA EM COCAL DO SUL
}

\section{LAYS JULIANI HESPANHOL | UNESC ALINE EYNG SAVI, Dra. | UNESC}

\section{CONTEXTUALIZAÇÃO}

Incentivar a cultura literária, é aumentar o nível de educação, informar o indivíduo e ajudá-lo a evoluir intelectualmente, dando-o liberdade criativa. Nos dias atuais, acontece o contrário, a cultura e a literatura estão interligadas, mas esquecidas e abandonadas em grande parte dos municípios brasileiros. Neste ponto entra em destaque, a falta de equipamentos públicos culturais de qualidade. Em Cocal do Sul, a realidade não é diferente. O município, situado no sul de Santa Catarina, sente a falta de qualidade nos seus poucos equipamentos públicos culturais. $O$ Centro de Cultura e Literatura está localizado numa edificação educacional particular, fechada em determinados dias e horários, restringindo o acesso da população ao acervo histórico e literário.

Criar espaços culturais e de diversificados usos, variando o programa de necessidades comum de um Centro de Cultura e Literatura municipal na área central da cidade de Cocal do Sul foi o objetivo geral deste trabalho final de conclusão de graduação, defendido em 2017.

\section{SOLUÇÕES DE PROJETO}

O projeto visa reintegrar a edificação de interesse histórico e patrimonial Palazzo Búrigo com a cidade, pela modificação do seu uso e inter-relação com edificação nova projetada. A implantação é composta por dois edifícios: o Palazzo e o centro de cultura e literatura municipal conectados por uma passarela. A tríade da cultura, educação e história fundamentaram e oportunizaram a elaboração da proposta, em busca da legibilidade dos volumes e da unidade do conjunto, destacou-se a principal diferença de estilos arquitetônicos, marcando a passagem do tempo especialmente pela linguagem, materialidade e estrutura. Neste ponto a tríade fica evidente na implantação do projeto bem como em toda a materialidade. A história do município tem relação direta com o Palazzo Búrigo e é demonstrada através da própria edificação e de seu uso, a educação é cominada pelo projeto com a relocação do acervo da biblioteca municipal e com as suas novas salas de estudo, já a cultura além do uso vem transposta na materialidade, soluções estruturais, de conforto térmico/ acústico e sustentáveis.

A escolha do aço para a estrutura levou em conta a flexibilidade dos espaços internos, facilidade e rapidez na montagem, mão de obra especializada na região, sustentabilidade da obra, anulação de desperdícios e resíduos de sobras, além de possibilitar grandes vãos e espaços integrados. Um átrio central organiza todos os fluxos verticais e horizontais entre as duas edificações, por ser o ponto central e de grande importância na edificação nova, possui um volume diferenciado marca visualmente e possibilita a entrada de iluminação natural, fazendo a troca de ar pelo efeito chaminé resultante, neste há uma ruptura na laje steel deck em todos os andares, e sua cobertura com mãos francesas libera a instalação da claraboia central, como mostra a figura 1.

O fechamento da edificação é feito basicamente por dois materiais, o vidro e a cerâmica. Onde há vidro nas fachadas há um recuo proposital criando um grande beiral, o que impede a incidência solar direta, não aquecendo os ambiente e não danificando o acervo. A preferência pela cerâmica levou em consideração o desempenho térmico e acústico, mas principalmente por evidenciar a cultura local, já que a cidade de cocal do sul é um polo cerâmico estadual. Nas fachadas onde há vidro e tem incidência solar pela manhã, foi projetada uma parede de cobogó, que além de possuir uma baixa condutibilidade térmica, afastada do vidro por alguns centímetros, cria uma camada de ar que dificulta a passagem do calor para dentro do ambiente, marcando visualmente as salas de uso cultural. Nas fachadas com incidência solar direta no período da tarde, que possuem fechamento em alvenaria convencional, foi projetado painéis de fachadas ventiladas com sistema de grampo oculto, que destacam o porcelanato e criam um efeito chaminé entre a parede e a fachada ventilada, dificultando a passagem do calor e refrigerando a parede.

Para a cobertura pensando na sustentabilidade e no conforto térmico de toda a edificação, o fechamento é feito por um telhado verde, que é responsável por captar a 
água da chuva, está é armazenada nos espelhos d'água desenhados no térreo que compõe o paisagismo, esta água em utilizado para molhar todos os blocos de vegetação.

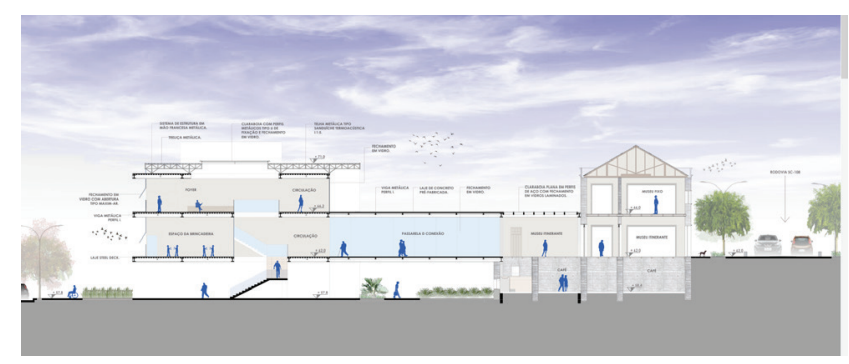

Figura 1 - Corte Transversal BB' Fonte: Autores

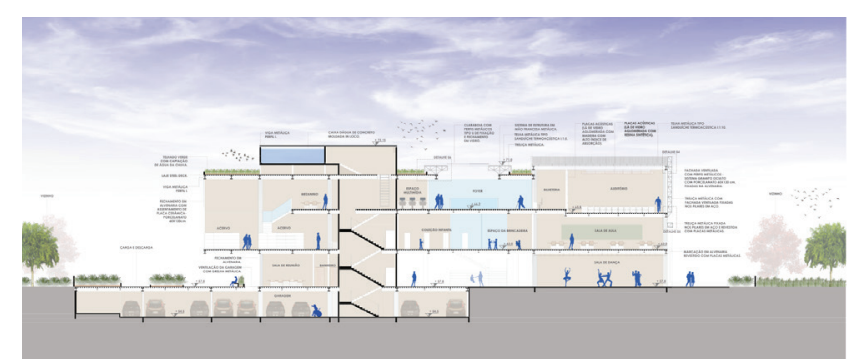

Figura 2 - Corte Longitudinal $A A^{\prime}$

Fonte: Autores

A cultura e a educação influenciam diretamente no desenvolvimento intelectual humano, auxilia na formação de opinião e ensina o pensamento crítico e criativo. Uma edificação que servirá como espaço para educação e cultura, deve como princípio ensinar para o futuro, com toda a sua bagagem histórica local, demostrar a sustentabilidade e poder educar o indivíduo através da nova edificação direcionou as soluções do projeto adotadas. 